\title{
Ten Years of the Global Labour Journal: Reflecting on the Rise of the New Global Labour Studies
}

\author{
Edward Webster, University of the Witwaterstand, South Africa \\ Robert O'Brien, McMaster University, Canada
}

\begin{abstract}
The article examines the origins of the Global Labour Journal (GLJ) and its goal of broadening labour studies. It shows how, over the past decade, the GLJ has recorded and analysed the forms of action and organisation that fall outside the traditional focus of labour studies. Through a range of careful case studies, the Journal has made an important contribution to the growing field of global labour studies. The two topics that have been the focus of most attention across all types of submissions have been: 1) precarious work and new forms of labour struggles; and 2) international trade unionism or transnational/global labour. The Journal has been successful in giving a platform to content from the Global South, but it is uneven and limited. Another major limitation is the failure to bridge the divide between the big questions raised in the Marx/Polanyi debates during the early phase of the Journal with the more concrete accounts of labour rediscovering its power on the periphery of labour movement. The article concludes by pointing towards possible options facing labour and the choices facing the GLJ.
\end{abstract}

\section{KEY WORDS}

Global labour; global labour studies; precarious work; future of labour

Since the turn of the century labour analysts and activists have been writing about the emergence of a new labour internationalism and/or a new global labour studies (NGLS) (Mazur, 2000; Lambert and Webster, 2001; Munck, 2002; Webster, Yates and O'Brien 2010; Brookes and McCullum, 2017). The precise content of the practice and field varies between analysts. This article examines the emergence of a new global labour studies as elaborated in the pages of the Global Labour Journal (GLJ) over the past decade. ${ }^{1}$ We argue that the GLJ's version of new global labour studies stresses labour's struggles with precarious work in Southern and Northern countries, as well as new forms of internationalism and transnationalism. It is multidisciplinary, with considerable contributions from female and Southern scholars. However, the relationship between the new labour studies and labour itself is unclear, as is its ability to confront the rising power of right-wing populism and the overreaching problem of climate change.

We begin by reviewing the emergence of new global labour studies before elaborating the origins and history of the Global Labour Journal. This is followed by an analysis of GLJ's major themes and the gender distribution and national/regional origins of its contributors. We consider

\footnotetext{
${ }^{1}$ We are grateful for the detailed and constructive comments from three anonymous reviewers and to Katherine Joynt and Utku Akman for their assistance in gathering the data used in our analysis.
} 
some of the Journal's limitations before concluding about its place in the field of labour studies and practice.

\section{The Rise of a New Global Labour Studies}

In a context where traditional trade unions are in decline, the rise of a new global labour studies is something of a puzzle. If organised labour is of declining importance, how could labour studies be on the rise? The answer is that the new labour studies is identifying the new initiatives, the new forms of organisation and sources of power that are emerging at the periphery of the traditional labour movement. There is, writes Jennifer Chun,

a growing interest in a new political subject of labour ... women, immigrants, people of colour, lowpaid service workers, precarious workers ... groups that have been historically excluded from the moral and material boundaries of union membership ... Rather than traditional scholarship on industrial relations, new labour scholars are exploring transformations occurring at the periphery of the mainstream labour movements (Chun, 2012: 40).

In their article in the Global Labour Journal, Marissa Brookes and Jamie McCallum suggest that:

The past two decades have seen a dramatic upsurge in sustained, cross-border labour activism, or labour transnationalism. Spanning North-South divides, industrial and service economies, and racial and gender lines, workers and their organisations have attempted, sometimes successfully, to meet capital at its own scale (Brookes and McCallum, 2017: 201).

They argue that, in contrast to labour scholars of the past, today's scholars believe "the new spirit of labour transnationalism strives for greater democracy, diversity and inclusivity, and tries to emphasise direct, concrete solidarity actions informed by strategic research and decentralised information networks" (Brookes and McCallum, 2017: 200). They refer to this emerging field of study as the new global labour studies (NGLS). ${ }^{2}$

The growth of a new global labour studies can be seen in the emergence of new blogs such as the Global Labour Column, LabourStart and Andreas Bieler's blog on Labour and Global Restructuring. At a deeper level the book review section of the GLJ continues to review new, innovative book-length manuscripts on a wide range of issues covered in the NGLS. Examples abound: Kate Bronfenbrenner's (2007) edited collection on cross-border labour action; Robin Rodriguez's (2010) account of the role of the Philippines as a broker state in the export of migrant labour across the globe; Webster, Lambert and Bezuidenhout's (2008) examination of labour's response to globalisation in Australia, South Korea and South Africa; Verity Burgmann's (2018) comprehensive examination of globalisation and labour in the twenty-first century; the implications

\footnotetext{
${ }^{2}$ Brooke and McCallum distinguish between an earlier version of global labour studies that emerged in the 1980s, the New International Labour studies (NILS), and the current version, the New Global Labour Studies (NGLS). They suggest that, "Whereas the former sees national labour movements interacting across their respective borders, the newer group of scholars has been more likely to imagine a truly cosmopolitan or global movement constituted by workers with increasingly tenuous ties to their home countries, nationstates and national labour movement traditions"(Brookes and McCallum, 2017: 2003).
} 
for labour of Chinese investment in Africa in Ching Kwan Lee's (2017) The Specter of Global China; Amrita Pande's (2014) exploration of transactional commercial surrogacy in India.; and Lu Zhang's (2015) detailed ethnographic study of the changing work organisation and labour protests on the shop floor of the Chinese automobile industry.

The interdisciplinary nature of the NGLS can be seen in the growth of global labour history. Marcel van der Linden (2008) breaks with methodological nationalism and Eurocentrism and has developed a labour history which integrates the history of slavery and indentured labour using the literature from diverse regions, epochs and disciplines. Richard Croucher's (2013) exploration of the turn towards transnational history and global unionism is another example in the field of history. In the field of geography, there has been a flowering of studies that focus on spatial relationships and geographic trends in the global economy. Here the work of Noel Castree and his colleagues (2004) and Andrew Herod (2001) stands out for pioneering this new approach to geography.

New academic courses on global labour have been established. The most ambitious has been the Global Labour University (GLU) with campuses at Kassel University and the Berlin School of Economics and Law in Germany, the University of the Witwatersrand in South Africa, the Tata Institute of Social Science and Jawaharlal Nehru University in India, the University of Campinas in Brazil and most recently Penn State University in the USA. There is also a new Masters programme on Labour, Social Movements and Development at the School of Oriental and African Studies in England.

A clear indication of a new field of study is the establishment of a journal to provide an outlet for this new area of specialisation. In 2004 a new journal called Work Organisation, Labour and Globalisation was launched. Huws, the founding editor, argued that:

The globalisation of world trade with the use of information and communication technologies is bringing about a new international division of labour, not just in manufacturing industries, as in the past, but also in work involving the processing of information.... The dynamics of this new global division of labour cannot be captured adequately within the framework of any single academic discipline. On the contrary, they can only be understood in the light of a combination of insights from fields including political economy, the sociology of work, organisational theory, economic geography, development studies, industrial relations, comparative social policy, communication studies, technology policy and gender studies (Huws, 2004: 1).

The launch ten years ago of the Global Labour Journal is another example of a journal designed to provide a forum for this new scholarship. In this article we focus on the GLJ to provide an insight into the methodology and substantive issues coved by the NGLS. The first edition contained an Editors' Note outlining the purpose and goals of the journal (Webster et al., 2010). The editors argued that a new online, open access journal was needed to disseminate the work of a new and emerging field of global labour studies which:

- examined new forms of labour action, organisation and ideas emerging in the age of globalisation;

- included work from other areas of sociology, such as the sociology of social movements and the sociology of work, as well as other disciplines such as labour geography, comparative politics, international studies and global political economy;

- recorded and analysed those forms of action and organisation that fall outside the traditional focus of labour studies to include labour-linked NGOs, community organisations and other 
labour linked organisations;

- described and analysed the responses of existing labour organisations and labour market institutions to these global challenges.

After a decade of publication, it is reasonable to ask whether the Journal has been successful in support of this field of "new global labour studies", what the content of this field is and what shortcomings the Journal has experienced. Our analysis indicates that the GLJ has succeeded in providing a forum for scholarly research in this new field but that it has made limited gains in developing a coherent body of social scientific knowledge on labour in the global economy. In the context of deepening inequality worldwide, the challenge facing the Journal is to broaden the range of contributions and bring together its multiplicity of case studies into a deeper understanding of the options labour faces in the age of digital global capitalism.

\section{Journal Origins and Brief History}

The immediate origins of the Global Labour Journal date back to the meeting of Research Committee 44 (Labour Movements) of the International Sociological Association (ISA) in Durban, South Africa in 2006. However, the decision to launch a journal on global labour reflects the profound changes taking place within labour worldwide. RC44 had begun as an ISA Working Group in the late 1980s to encourage international research on Labour Movements, with a focus on their role both in industrial relations and in the political arena. The majority of members were from Western Europe and to a lesser extent the USA, with a handful of members in Africa, Asia and Latin America.

At the 1998 ISA congress in Montreal, Richard Hyman was elected president and Edward Webster secretary of RC44, now a formal Research Committee of the ISA. At this gathering two important decisions were made by RC44. The first was to deepen the links of its members with the labour movement. At the meeting, members strongly affirmed their support for the core labour standards which it held to be fundamental human rights:

- freedom of association;

- $\quad$ right to organise and bargain collectively;

- prohibition of forced labour;

- elimination of exploitative forms of child labour;

- non-discrimination in employment or occupations.

It also agreed to undertake a regional meeting of RC44 in South Africa to coincide with the conference of the Southern Initiative on Globalisation and Trade Union Rights (SIGTUR) to be held in Johannesburg in November 1999. Rob Lambert had recently joined the RC44 Executive and was also the coordinator of SIGTUR. Lambert argued that there was "a need to draw in labour committed intellectuals to assist in the process of analysing the impact of global change on different sectors as well as emerging alternatives and strategies to gradually move the unions in a new direction" (Lambert, 1999: 4; see O’Brien [2019] for an analysis of the evolving relationship between academics and SIGTUR).

The second decision was to broaden the reach of RC44 by actively recruiting the participation of members from the Global South. As Hyman (1999: 3) wrote in the expanded Newsletter that 
followed the conference, "A key aim in the next few years must be to make our activities truly global". ${ }^{3}$ Hyman went on to argue that:

Labour movements seem to be entering a new epoch.... The restructuring of national economies and national labour markets, and the exposure of national industrial relations systems to external challenges, have forced union movements with varying degrees of success to attempt to 'modernise' and to take halting steps towards greater international awareness and solidarity. The transformations in the real world of labour confront scholars with the challenge to build new modes of understanding and explanation (Hyman, 1999: 3).

By the time RC44 met in 2006 in Durban, both the composition of RC44 and the focus of its research had begun to change. The decision to reorient the Research Committee away from a focus on Northern trade unions to labour experiences around the world was now bearing fruit A newly elected RC44 President and board members reflected this diversity. A second development was the discussion about the large amount of research that was emerging from countries outside of the traditional bastions of trade union studies in Europe and the United States. Much of this work examined informal labour or unorganised labour outside of trade unions in a wide range of countries. Some of this research emerged from labour studies or industrial relations, but contributions were also coming from fields as diverse as gender studies and international relations.

Some of the discussion that flowed from an analysis of these new forms of labour studies centred around the observation that this research did not have a natural publication home. In preparation for the conference in Durban, Edward Webster, now President of RC44, had suggested that:

[It is] now time to consolidate our expanded membership with a regular high-quality academic publication. What will be distinctive in our debates in Durban is that the voices of Southern scholars will be at the forefront of research findings. RC44 no longer reflects the interests of the North only (Webster, 2006: 3).

At the conference it was decided by RC44 members that they should found their own journal to publish this work and to give a voice to research on the wide variety of labour movements and organisations outside of Europe and the United States. One of the RC44 members, Robert O'Brien, had recently finished a term co-editing an international journal in the field of social policy (Global Social Policy) and volunteered to work with Webster to develop a proposal for a new global labour studies journal.

The proposal that emerged from their discussions was for an online, open access journal which could serve as a forum for a new global labour studies. The rationale for an online and open access journal was that work would be freely available to labour studies scholars and practitioners around the world who had an Internet connection. This would avoid the restrictions imposed by commercial publishing houses, which limited access to libraries or people who could afford subscriptions.

Although open access publishing is becoming more common today, it ran very much against the norm for academic work when we first started discussing the idea of a journal in 2006. Even though the vast majority of academic articles written in the Social Sciences were funded by

\footnotetext{
${ }^{3}$ An important innovation introduced after the 1998 conference was a regular RC44 Newsletter which ran twice a year until 2010 when it became an E-Newsletter. It carried short articles and reports on global labour; it was the embryo of the GLJ. The first seventeen editions were edited by Anthea Metcalfe, a member of RC44 at the time.
} 
government grant agencies and the majority of the authors were employed at publicly funded universities, the norm was for authors to give their work away to commercial publishing houses or university presses who then published it in their journals for a profit. The commodification of academic knowledge was, and is, especially troublesome for scholars who have devoted their lives to analysing the exploitation of labour. A more serious issue was that the commercial publishing model excluded large numbers of readers who could not afford subscriptions or did not have access to university libraries. This is felt more widely in poorer countries and among the interested public outside of universities. The problematic aspects of the commercial model have recently been recognised by a number of national funding agencies, who increasingly insist on publicly funded research being published in open access journals (Government of Canada, 2016).

Another important aspect of choosing to adopt an online, open access format is that it would potentially disseminate the Journal's articles, reviews and Global Issues sections to an audience beyond the academy. Members of social movements, trade unionists, NGOs and workers themselves could access the material provided they had the technical means (a computer and an Internet connection) and language ability (proficiency in English). This still excluded some people, but it was an advance on the commercial journal format.

The online, open access model adopted by GLJ faced two major challenges. One challenge was that of resources. Commercial publishers operate at a profit and funnel some of their funds to journals for the administrative support needed to run the journals. They also provide the expertise in formatting and printing the journal itself. The other large issue was a reputational one. Would people be willing to publish high quality academic work in an online, open access journal? As the Journal editors began to put the plan into action, more than one senior academic in the labour studies field expressed doubt that an open access, paperless journal would be able to attract submissions or readers. Concerns were raised about the quality and reputation of such an undertaking.

The financial and technological problems were solved through a number of steps. The Journal's start-up costs and very modest budget was provided through the research professorship of one the editors. Robert O'Brien held the LIUNA Mancinelli Professorship in Global Labour Issues at McMaster University and used some of its income to support the Journal. By coincidence, the McMaster Library was moving into the practice of online journal publishing and was able to assist with hosting the new journal using a format provided by Berkeley online press (bepress). The Journal required an experienced managing editor to manage submissions, run the system and format articles for publication. O'Brien was able to employ Kara Vincent who had been his managing editor at Global Social Policy. When Vincent left, he was able to secure the services of of another capable editor, Angela Ceccato.

The issue of journal reputation was not an easy one to solve. Online and open access publishing was in its infancy and ran against the common practice of academics to publish in particular commercial journals. Yet surely the reputation of journals is an academic judgement made by figures in the field rather than by publishers. Publishers try to guarantee quality, but they do not produce the content; that task is undertaken by academics themselves.

Our strategy to build the reputation and attract submissions was twofold. One target group was new scholars or scholars outside of the traditional centres of labour studies eager to disseminate their work to a global audience. Being online and open access meant that they would potentially have a larger audience than a traditional printed journal. In addition, the new scope of the GLJ would look favourably on their material. The second target group comprised wellestablished scholars who would lend their prestige to the Journal by publishing in it. We were fortunate in acquiring for the first edition the services of Paul Bowles and John Harriss, both 
leading scholars in their fields. They edited our first Special Issue on Globalisation(s) and Labour in China and India, with leading scholars such as Barbara Harriss-White contributing. Another important early contribution by an established scholar was Michael Burawoy's (2010) piece "From Polanyi to Pollyanna: The False Optimism of Global Labour Studies". His contribution sparked a heated debate that was followed up in subsequent issues. The article was widely read and brought readers to the Journal. The GLJ's reputation was also enhanced by prominent academics joining the Editorial Board. Their contributions were purely altruistic since the Journal was a new and slightly risky venture.

The original idea was that the editorial team would be equally balanced between the Global North and the Global South. During the first five years Robert O'Brien representing the Global North and Edward Webster the Global South were assisted by managing editors Kara Vincent and Angela Ceccato. ${ }^{4}$ After five years, in December 2014, the Journal was transferred to a new editorial team composed of Rina Agarwala (Johns Hopkins), Jenny Chan (Hong Kong Polytechnic), Alexander Gallas (Kassel), Katherine Joynt (Reviews Editor, Witwatersrand), Ben Scully (Witwatersrand) and another excellent managing editor, Karin Pampallis. In 2017 Jörg Nowak (University College Dublin) came on board as the new Reviews Editor, and in January 2019 Maria Lorena Cook (Cornell) and Madhumita Dutta (Ohio State) replaced Agarwala and Chan, who rotated out.

A new source of funding was found from the Global Labour University and three of its partners - the International Center for Development and Decent Work (ICDD) in Germany, the Center for Global Workers' Rights (CGWR) in the United States, and the Society, Work and Development Institute (SWOP) in South Africa. In July 2014, at the ISA congress in Japan, the GLJ became the official journal of RC44.

\section{Journal Themes}

A good way to get a sense of the nature of global labour studies as portrayed by the Journal is to undertake a survey of the major themes that have been examined in its published articles, book reviews and Global Issues (GI) pieces (see Table 1). ${ }^{5}$ The Global Issues section was created to provide a space for short, non-peer-reviewed analyses, records or descriptions that illuminate and inform the readership of current responses by labour to the challenge of globalisation. This addition to traditional articles and book reviews was undertaken to encourage the flow of ideas and discussion between different parts of the globe - especially important for scholars based in the Global South who face obstacles inserting themselves in Northern dialogues and for people based in the Global North who lack access to perspectives and ideas from the majority of the world's population.

The two topics that have been the focus of most attention across all types of submissions (articles, reviews and GI pieces) have been: 1) precarious work and new forms of labour struggles; and 2) international trade unionism or transnational/global labour. Contributions on precarious work and labour organisations' response to precarity was the leading theme with 48 contributions. International union activity or labour transnationalism came second with 30 contributions. The

\footnotetext{
${ }^{4}$ Charlotte Yates (McMaster) was part of the initial editorial team but resigned after a year when she undertook a deanship at the university.

${ }^{5}$ Each contribution was coded to fit only one theme. Articles with multiple authors had each author's geographic location coded.
} 
next set of topics that appeared frequently were investigations of different forms of neo-liberalism and globalisation's impact on labour (22), and concern with labour standards (22). The labour standards category included national studies, investigations of international labour standards and labour standards along a global supply chain. Labour's relationship with a variety of social movements was the fifth area of interest (18), while articles dealing with industrial relations or trade union politics came sixth (15). This was followed by pieces on labour and the welfare state in the North and the South (14), and gender and work (12). Topics that appeared between five and ten times included: labour and the environment (9), home/unpaid/forced work (8), strikes (6) and technology (5).

Focusing on peer-reviewed articles (which reflect original research) reveals a slightly different picture. Precarious work is clearly the leading category (25) followed by international unionism (19) and labour standards (18). There is then a gap with a variety of topics having less than ten contributions: social movements (8), gender (7), industrial relations (7) and the environment (5).

Table 1. GLJ's major themes across all types of submissions, 2010-2019

\begin{tabular}{|c|c|c|c|c|}
\hline $\begin{array}{l}\text { Theme addressed in GI piece, } \\
\text { article or book review }\end{array}$ & $\begin{array}{c}\text { Number of } \\
\text { Global } \\
\text { Issues } \\
\text { articles }\end{array}$ & $\begin{array}{l}\text { Number of } \\
\text { peer- } \\
\text { reviewed } \\
\text { articles }\end{array}$ & $\begin{array}{c}\text { Number of } \\
\text { books } \\
\text { reviewed }\end{array}$ & Total \\
\hline $\begin{array}{l}\text { Worker resistance/precarious } \\
\text { work/new sources of power }\end{array}$ & 11 & 25 & 12 & 48 \\
\hline $\begin{array}{l}\text { International trade unionism/ } \\
\text { transnational/global labour }\end{array}$ & 2 & 19 & 9 & 30 \\
\hline Neo-liberalism and globalisation & 1 & 6 & 15 & 22 \\
\hline Public sociology/Polanyi & 6 & 3 & 2 & 11 \\
\hline Labour standards & 1 & 18 & 3 & 22 \\
\hline Labour and migration & 2 & 5 & 6 & 13 \\
\hline Labour and social movements & 5 & 8 & 5 & 18 \\
\hline Gender and work & 0 & 7 & 5 & 12 \\
\hline The welfare state & 1 & 2 & 11 & 14 \\
\hline Home/unpaid/forced work & 1 & 4 & 3 & 8 \\
\hline $\begin{array}{l}\text { Labour and environment (including } \\
\text { climate change) }\end{array}$ & 1 & 5 & 4 & 10 \\
\hline Industrial relations/union politics & 0 & 7 & 8 & 15 \\
\hline Technology & 0 & 4 & 1 & 5 \\
\hline Strikes & 0 & 4 & 2 & 6 \\
\hline
\end{tabular}

It is also possible to see the Journal's themes evolve over time. The initial five volumes featured a number of articles drawing on the work of Marx and Polanyi. The second five volumes 
took a more empirical approach and featured case studies of particular unions, regions or countries. This included an extended discussion of the power resources approach to understanding labour issues. A significant minority took a different approach and were more conceptually focused on issues such as neo-liberalism or transnationalism. Many articles investigated the interaction of local and global phenomena, attempting to discern the interaction between different scales.

Our analysis of the content of the Journal confirms Brookes and McCallum's (2017) identification of the major themes of the new global labour studies. They identify two major subsets of NGLS scholarship. One is a theoretical strand, inspired by Marx and Polanyi, and concerned with the possibilities of labour as a counter-movement to the power of global capital. They describe this strand as labour-as-counter-movement. They suggest that another strand has emerged in the NGLS that examines individual cases of labour internationally and their strategies. They label this strand as strategy-focused and see this approach as emphasising labour's agency and power to shape globalisation. However, the Journal also reveals another constant theme, which is that of the increasing precarity of labour across sectors and countries.

\section{Gender and Geographic Profiles}

One of the objectives of starting the Journal was to give voice to a wider variety of scholars, both in terms of gender and region. Approximately 33 per cent of contributions have been from women and 32 per cent from scholars or activists based in the South (see Tables 2 and 3).

Table 2. Gender distribution of contributors over all submissions, 2010-2019

\begin{tabular}{|l|c|c|}
\hline Gender & Appearances & Percentage \\
\hline Male & 228 & $67 \%$ \\
\hline Female & 111 & $33 \%$ \\
\hline
\end{tabular}

The contributions from women declined slightly over time as they made up 35 per cent in Volumes 1-5 and 31 per cent in Volumes 6-10. However, the percentage of contributions from the South is actually higher than 32 per cent since numerous contributions were coded as being from the North because of the authors' institutional affiliation. In fact, many contributions were from individuals who are from the South originally and write on topics outside of the North. This was especially the case for scholars from China and India. Within the North, the leading countries for contributors were the UK (48), US (44), Canada (42) and Germany (41). The relatively large number of contributions from Germany and the UK can be partially attributed to some of the Journal's editors being based in those countries. Among Southern countries, South Africa (50) led by a wide margin. South Africa is the only country to have hosted a journal editor over all ten volumes. Its 50 contributions exceeded all other countries, North or South. India (16), China (12) and Brazil (10) made up the bulk of the rest of the Southern contributions, followed by Argentina (6), Mexico (4) and other sub-Saharan states (4). Turkey (3) and Bangladesh (1) rounded out the contributions. 
Table 3. Geographic distribution of contributors over all submissions, 2010-2019

\begin{tabular}{|l|c|c|}
\hline Region/Country & Appearances & Percentage \\
\hline & & \\
\hline North & 225 & $68 \%$ \\
\hline UK & 48 & \\
\hline US & 42 & \\
\hline Canada & 41 & \\
\hline Germany & 11 & \\
\hline Australia & 10 & \\
\hline Netherlands & 7 & \\
\hline Switzerland & 6 & \\
\hline France & 14 & \\
\hline Other Euro & 2 & \\
\hline New Zealand & & \\
\hline & 106 & \\
\hline South & 50 & \\
\hline South Africa & 16 & \\
\hline India & 12 & \\
\hline China & 10 & \\
\hline Brazil & 6 & \\
\hline Argentina & 4 & \\
\hline Mexico & 4 & \\
\hline Other sub-Saharan Africa & 3 & \\
\hline Turkey & 1 & \\
\hline Bangladesh & & \\
\hline
\end{tabular}

If we analyse the number of articles submitted between 2015 and 2019 (151) that eventually led to publication (44), an interesting pattern emerges (Table 4). ${ }^{6}$ In terms of articles published, the Global North - US/Canada, UK, Continental Europe and Australia - continues to dominate (27 out of 44) with US/Canada the highest contributor (11), followed by the UK (8), Continental Europe (7) and Australia (1). In the Global South the major contributors are Africa (6), Latin America(6) and South Asia (4), with one from the Middle East and none from East Asia. The highest number of rejections were also from East Asia ( 6 out of the 6 articles submitted). This indicates that the Journal might need to take proactive steps to assist authors from the Asian region to meet the GLJ's publication requirements.

Reflecting upon these numbers it is clear the Journal has more work to do. It is disappointing that the publication of female authors has stalled in the low 30 per cent range. Similarly, although gender approaches feature in Journal content, they are not in the top seven topics. More thought should be given about concrete actions that could be taken to increase female contributions and gender content. The Journal has been successful in giving a platform to content from the Global South, but it is uneven and limited. It is still only a third of all Journal contributions, but if you focus on articles only it drops to about a quarter. Having a close relationship with South African editors and an institutional affiliation at the University of the Witwatersrand has contributed to a surge of Southern African content. Other areas of the world are less well represented. Although there were twenty contributions from South American authors (six of which are articles), the

${ }^{6}$ We would like to thank Karin Pampallis, managing editor of the GLJ, for producing Table 4. 
Journal's publication only in English remains a barrier for many scholars and activists in that region. There have been no article publications from East Asia. Critical content from scholars working at Chinese universities is limited given state policies limiting freedom of expression. Indian scholars appear in the Journal, but not at a level proportionate to the size and importance of the Indian labour force. There are also other important areas of the world (such as the Middle East) that are largely absent from the journal. The absence of articles from a region such as the Middle East could have multiple causes: the barrier of the English language, a lack of profile or network of the Journal in this region or limited work on this subject coming from the region.

Table 4. Summary of article submissions, 2015-2019

\begin{tabular}{|l|c|c|c|c|}
\hline Area* & Submitted & Rejected & In Processing** & Published \\
\hline Africa & 30 & 22 & 2 & 6 \\
\hline Australia & 2 & 0 & 1 & 1 \\
\hline East Asia & 6 & 6 & 0 & 0 \\
\hline Europe & 33 & 21 & 5 & 7 \\
\hline Latin America & 10 & 3 & 2 & 6 \\
\hline Middle East & 6 & 3 & 3 & 4 \\
\hline South Asia & 25 & 18 & 1 & 8 \\
\hline UK & 13 & 4 & 5 & 11 \\
\hline US/Canada & 25 & 9 & $\mathbf{2 0}$ & 44 \\
\hline Total & $\mathbf{1 5 1}$ & $\mathbf{8 6}$ & . & 1 \\
\hline
\end{tabular}

* For the purposes of this analysis: "South Asia" includes India, Sri Lanka, Bangladesh, Pakistan and Afghanistan; "Europe" refers to Continental Europe; "Latin America" includes Mexico, Central America and the Caribbean.

** "In Processing" refers to 2019 submissions which are still out for peer review; no decision has yet been taken on whether or not to publish these submissions.

\section{Journal Limitations}

The Global Labour Journal is a product of the people involved in its creation and maintenance, and as a result suffers from some of their limitations. It has been successful in securing sources of funding from outside of the commercial publishing world and thus is able to publish open access. However, the cost of this independence is that the Journal runs on a very limited budget and has been unable to finance more ambitious undertakings. For example, additional funding would allow it to engage translation services and publish in languages other than English. This would attract a wider variety of content and bolster its claim to being a truly global journal.

Even though the Journal is online, it relies heavily on the intellectual and professional networks of its editors and advisory board to attract articles and call on reviewers. Thus, content from countries where editors are based (South Africa, United Kingdom, Germany, Canada/US) have a disproportionately large number of contributions. Similarly, although the Journal publishes material from a range of disciplines, it is heavily weighted towards sociology, as one would expect from a journal officially linked to the International Sociological Association.

Another major limitation is the failure to bridge the divide between the big questions raised in the Marx/Polanyi debates during the early phase of the Journal with the more concrete accounts of labour rediscovering its power on the periphery of labour movement. Brookes and McCallum capture this point best when they write, "In general, we believe that the field, diverse as it is, has 
been largely, and for some good reasons, pointed inward". They go on to argue " for more middlerange theories and closer engagement with social science" (Brookes and McCallum, 2017: 212213).

\section{Conclusion}

Over the past decade the GLJ has recorded and analysed the forms of action and organisation that fall outside the traditional focus of labour studies. Through a range of careful case studies, the Journal has made an important contribution to the growing field of global labour studies. What emerges from our analysis of the content of the GLJ is that we need to move away from narratives that suggest labour is powerless because unions have fallen on difficult times. The precarious workers analysed in the Journal do have agency and power. They are beginning to cross the divide between the historically organised permanent workers and the growing number of precarious workers (Spooner and Mwanika, 2018). New and hybrid forms of organisation are forming on the periphery of the labour movement across the globe, but especially in the Global South. Similarly, the international and transnational activity of labour is vital as workers struggle to cope with capital mobility and supra-state regulation.

A lively and robust debate took place in the early editions of the Journal on the possibilities of a Polanyian counter-movement against the unregulated market. What was often ignored in this debate is that Polanyi's work also contains a warning; at times workers do turn inwards and become fatalistic, even xenophobic. Insecurity may not necessarily result in progressive countermovements. It could lead, and it has led, to its opposite. Indeed, this was the central preoccupation of Polanyi's (1944) classic work, namely that the unregulated liberalisation of markets between 1918 and 1939 could lead to the rise of fascism. It was this response to liberalisation that led to Polanyi's concern with democracy. And it is the return of fascist-like movements in Germany, in Europe and in North America through to the Global South that is leading to a deep pessimism about the future of labour (Dörre, 2018).

Between the overriding optimism and "uncompromising pessimism" of the early debate in the Journal, what did emerge is that Polanyi under-theorised how counter-movements are constructed. Who and what will comprise the counter-movement emerged as unclear; what did emerge is that labour is only one part of any potential counter-movement

As Klaus Dörre (2018: 346) argues in his article on the right wing in the labour movement in Germany: "If trade unions want to refute the accusation of the New Right that they are part of the establishment, they must once again become more of a social movement." It is precisely this broadening role of labour in its involvement in challenging inequality that Michelle Williams describes in a Special Issue of the Journal on inequality:

The campaigns on the end of the spectrum with a high level of union involvement include campaigns that directly and indirectly address issues of inequality such as the Climate Justice campaign in South Africa, the Minimum Wage campaigns in Germany and Brazil, the struggle for redistribution in Argentina, and the struggle for gender equality in Brazil. While unions are leading all of these campaigns, they are doing so by building links with a broader base of support and through both typical and untypical campaigns (Williams, 2015: 266).

Whether labour is able to play this transformative role remains to be seen. Other options are possible. The gradual marginalisation of labour is one option. A "dualization of union representation and policies" (Visser, 2019: 8), where unions defend their positions and resist where 
they are currently strong, is another option, leaving the majority of workers without a voice.

Or, a final option would be that unions are replaced by other forms of social action and representation, such as legislation, employer initiatives, business models, NGOs or intermittent unorganised action (Visser, 2019: 10). It is certainly the case that, with the rise of the populist right from Brazil to Britain, the outlook for labour is bleaker now than it was at the time of the Journal's founding.

Lurking in the background of labour's ongoing struggle with capital in local, national and global scales is the rapidly approaching prospect of environmental catastrophe from climate change and widespread species extinction (IPCC, 2018; IPBES, 2019). While the Journal has addressed this issue in some contributions, it has been a relatively under-developed theme. The pressure on workers and workers' communities from environmental degradation is likely to increase conflict between groups and with political and economic elites. The dynamics of this conflict are not yet clearly understood, and the GLJ could have an important role in exploring the issue.

What of the future? The GLJ has the potential to play an important role in deepening the understanding of the social science community, policy-makers and the labour movement more broadly about the challenges facing labour in the age of digital global capitalism. This could involve a return to the more interventionist role envisaged by some at the conception of the Journal, where the Journal would convene workshops or conferences with local and regional labour scholars and activists. On the other hand, the editors may feel that a more realistic goal in an environment where labour has a long road ahead if it is to become an effective voice for working people worldwide, is to focus on building its reputation as a high-quality academic journal. Whatever choice the Journal makes, the solid foundations laid in its first decade have established it as a central source for all those concerned with the future of the labour movement.

\section{REFERENCES}

Bronfenbrenner, K. (ed.) (2007) Global Unions: Challenging Transnational Capital Through Cross-Border Campaigns. Ithaca and London: ILR Press.

Brookes, M. and J. McCallum (2017) The New Global Labour Studies: A Critical Review. Global Labour Journal, 8(3): 200-2017.

Burawoy M. (2010) From Polanyi to Pollyanna: The False Optimism of Global Labour Studies. Global Labour Journal, 1(2): 301-313.

Burgmann, V. (2018) Globalization and Labour in the Twenty-first Century. London: Routledge.

Castree, N., N. Coe, K. Ward and M. Samers (eds.) (2004) Spaces of Work: Global Capitalism and the Geographies of Labour. London: Sage.

Chun, J. (2012) The Power of the Powerless: New Schemas and Resources for Organizing Workers in Neoliberal Times. In Cross-National Perspectives on Social Movement Unionism: Diversities of Labour Movement Revitalization in Japan, Korea and the United States, edited by A. Suzuki. Oxford: Peter Lang.

Croucher, R. (2013) The Turn to Transnational Labor History and the Study of Global Trade Unionism. Labor History, 54: 491-511.

Dörre, K. (2018) A Right-wing Workers' Movement? Impressions from Germany. Global Labour Journal, 7(3): 339-347.

Government of Canada (2016) Tri-Agency Open Access Policy on Publications. http://www.science. gc.ca/eic/site/063.nsf/eng/h F6765465.html?OpenDocument (accessed 18 January 2020).

Herod, A. (2001) Labor Geographies: Workers and the Landscapes of Capitalism. New York: Guilford Press.

Huws, U. (2004) Introduction. Work, Organisation, Labour and Globalisation, 1(1): 1-3. 
Hyman, R. (1999) RC44: Past, Present and Future. RC 44 Newsletter, May 1999.

Intergovernmental Panel on Climate Change (IPCC) (2018) Headline Statements from the Summary for Policy Makers. Special Report: Global Warming of $1.5^{\circ} \mathrm{C}$. www.ipcc.ch (accessed 15 December 2019).

Intergovernmental Science-Policy Platform on Biodiversity and Ecosystems Services (IPBES) (2019) Nature's Dangerous Decline: "Unprecedented" Species Extinction Rates "Accelerating". Media release, Monday, 6 May 2019. https://www.ipbes.net/news/Media-Release-Global-Assessment (accessed 25 January 2020).

Lambert, R. (1999) Southern Initiative on Globalisation and Trade Union Rights. RC44 Newsletter, May 1999.

Lambert, R. and E. Webster (2001) Southern Unionism and the New Labour Internationalism. Antipode, 33(3): 337-362.

Lee, C.K. (2017) The Specter of Global China: Politics, Labor and Foreign Investment in Africa. Chicago: University of Chicago Press.

Mazur, J. (2000) Labour's New Internationalism. Foreign Affairs, 79(1): 79-93.

Munck, R. (2002) Labour and Globalisation: The New Great Transformation. London: Zed Books.

O'Brien, R. (2019) Labour Internationalism in the Global South: The SIGTUR Initiative. Cambridge: Cambridge University Press.

Pande, A. (2014) Wombs in Labor: Transactional Commercial Surrogacy in India. New York: Columbia University Press.

Polanyi, K. (1944) The Great Transformation: The Political and Economic Origins of our Time. Boston: Beacon Press.

Rodriguez, R.M. (2010) Migrants for Export: How the Pbilippine State Brokers Labor to the World. Minneapolis, MN: University of Minnesota Press.

Spooner, D. and J. Mwanika (2018) Transforming Transport Unions' Organisation of Informal Workers: A Case Study of the ATGWU in Uganda. Global Labour Journal, 9(2): 150-166.

Van der Linden, M. (2008) Workers of the World: Essays Toward a Global Labor History. Leiden and Boston: Brill.

Visser, J. (2019) Trade Unions in the Balance. ILO/ACTRAV Working Paper. Geneva: International Labour Organization.

Webster, E. (2006). From Brisbane to Durban: Rediscovering the Power of the Labour Movement. RC44 Newsletter, 2(9), March.

Webster, E., R. Lambert, and A. Bezuidenhout (2008) Grounding Globalisation: Labour in the Age of Insecurity. Malden, USA, Oxford, UK and Carlton, Australia: Blackwell Publishers.

Webster, E., C. Yates, and R. O'Brien (2010) Global Labour Journal: A Scholarly Forum for Global Labour Studies. Global Labour Journal, 1(1): 1-2.

Williams, M. (2015) Transformative Unionism and Innovative Campaigns Challenging Inequality. Global Labour Journal, 6(3): 253-266.

Zhang, L.(2017) Inside China's Automobile Factories: The Politics of Labour and Worker Resistance. New York: Cambridge University Press.

\section{BIOGRAPHICAL NOTES}

Robert O'Brien is Professor of Political Science at McMaster University and former Associate Editor of the Global Labour Journal. [Email: obrienr@mcmaster.ca]

EdWard Webster is Professor Emeritus at the Society, Work and Politics Institute (SWOP), and Distinguished Professor, Southern Centre for Inequality Studies (SCIS) at the University of the Witwatersrand. [Email: Edward.Webster@wits.ac.za] 